
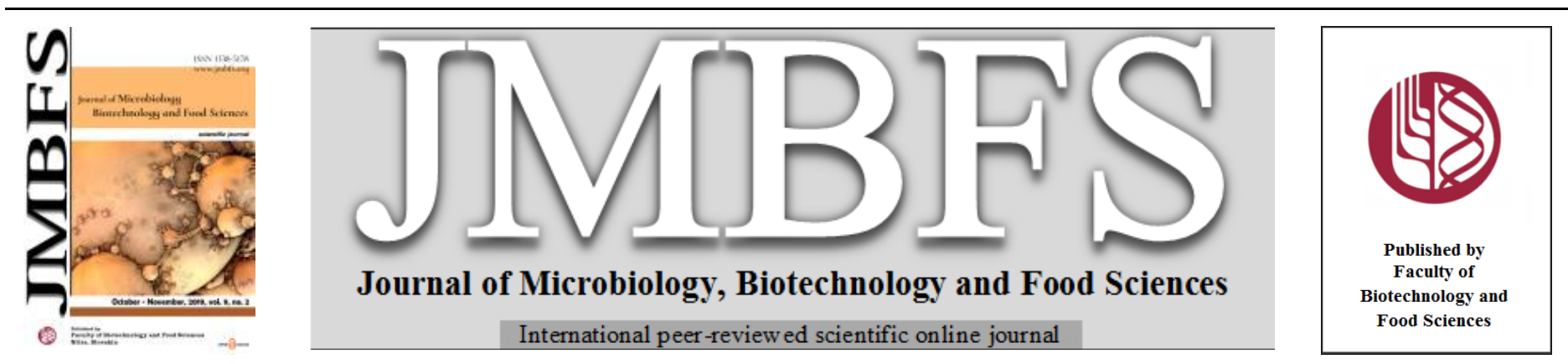

\title{
EFFECT OF ZINC METAL AT HIGH CONCENETRATION ON SECONDARY METABOLIC PATHWAYS IN PENICILLIUM CHRYSOGENUM STRAIN
}

\author{
Ghania Bourzama $^{1,2,3^{*}}$, Nadjet Ennaghra ${ }^{1,3}$, Boudjma Soumati ${ }^{1,3}$, Saliha Benoune ${ }^{2}$, Nesrine Atriche ${ }^{2}$ \\ $\operatorname{Address(es):~}$ \\ ${ }^{1}$ Laboratory of Biochemistry and Applied Microbiology, Department of Biochemistry, Faculty of Sciences, Badji Mokhtar University, Annaba, Algeria. \\ ${ }^{2}$ Laboratory of Applied Microbiology Department of Microbiology and Food Sciences, Faculty of Science, University of Jijel, Algeria. \\ ${ }^{3}$ Laboratory of Biochemistry and Environmental Toxicology, Department of Biochemistry, Faculty of Sciences, Badji Mokhtar University, Annaba, Algeria.
}

*Corresponding author: gbourzama@yahoo.fr

doi: 10.15414/jmbfs.2019.9.2.307-313

\section{ARTICLE INFO}

Received 25. 11. 2018

Revised 17. 6. 2019

Accepted 19. 6. 2019

Published 1. 10. 2019

Regular article

open $\partial_{\text {ACCESS }}$

\begin{abstract}
Environmental pollution by heavy metals is a recent global problem threatening human life through the food chain. The used of fungi provides an alternative solution to eliminate these heavy metals. The current study aims to study the change of secondary metabolic pathways of fungal strain tolerant of Zinc metal. Penicillium chrysogenum selected strain was isolated from the sand of beaches polluted with Zinc at East Algerian area. The optimization of Penicillium chrysogenum strain was carried out on Czapek Yeast Agar medium (CYA) at different temperature and $\mathrm{pH}$ values. The effect of Zinc on the production of secondary metabolites by Penicillium chrysogenum strain was determined on solid medium, Thin Layer Chromatography (TLC) plate and High Performance Liquid Chromatography (HPLC). The results revealed that Penicillium chrysogenum strain can develop in a wide range of temperature and $\mathrm{pH}$ with an optimum of $28^{\circ} \mathrm{C}$ and 6. It is capable to tolerate high concentrations of Zinc (up to $1400 \mathrm{mg} . \mathrm{l}^{-1}$ ). This study showed that high concentrations of Zinc (1200 and $\left.1400 \mathrm{mg} \cdot \mathrm{1}^{1^{-}}\right)$have a positive effect on antibiotic production, but they have a negative effect on the mycotoxin production except to neoxaline.
\end{abstract}

Keywords: antibiotic, fungi, heavy metal, mycotoxin, production, Zinc

\section{INTRODUCTION}

Soil and wastewater, particularly from industries contain high concentration of heavy metals which pass into human and animals through food chain (LópezErrasquín and Vázquez, 2003). Heavy metals are difficult to remediate. Therefore, environmental compartments (soil and water) are not able to eliminate these toxic metals (Krämer and Chardonnens, 2001). Chemical treatment methods have disadvantages which include high costs, high reagents and/or energy requirements and formation of toxic complex products that require disposal. Restoring metals in an efficient and economical procedure have necessitated the use of different options in metal-separating methods. Research shows that bioaccumulation of metals by organisms has been successful to some extent (Salinas et al., 2000). However, a long-term exposure of organisms mainly microorganisms at high metal concentration develops a resistance in them. Thus, the microorganisms isolated from contaminated wastewater and soil by metals with high concentrations represent a biological source for this metal removal (Parameswari et al., 2010).

A number of metals are required in minute amounts by most living organisms for normal maintenance. It is now known that Zinc at low concentration is essential for the activity of more than 25 enzymes, nucleic acid metabolism, wound healing and the synthesis of many industrially and medically significant microbial secondary metabolites (Valee and Wacker, 1970; Saxena et al., 2006). Some heavy metals particularly have been found recently in relatively high levels. The presence of these metals at high concentration causes lethal effect on living systems including fungi. The toxicity of these metals was affected by different factors like $\mathrm{pH}$ and the composition of growth medium. The ability of metals tolerance and uptake is varied with fungi (Saxena et al., 2006).

Among the more fascinating properties of fungi is their ability to synthesize a wide variety of secondary metabolites typically defined as small molecules that are not necessary for normal growth or development (Fox and Howlett, 2008). Penicillium is known as a genus of Ascomycetous fungi tolerant of various heavy metals at high concentrations. It is particularly known for its ability to produce important bioactive compounds in the field of industry and pharmaceuticals due to highly diversified spectrum of secondary metabolites, including antibacterial (Gloer, 2007), and potent mycotoxins (Keating and Figgitt, 2003). Production of these secondary metabolites from Penicillium strains is intensely being examined particularly from the strains of unexplored habitats. The subgenus Penicillium chrysogenum has been commercially exploited for many decades due to its high production of $\beta$-lactam antibiotics such as penicillin G (Weber $\boldsymbol{e t}$ al., 2012). Next to penicillins, other secondary metabolites such as roquefortines and glandicolines were isolated from liquid cultures of P.chrysogenum, which show pharmaceutically interesting properties, such as neurotoxic (Scott et al., 1976), antimicrobial (Clark et al., 2005; Koolen et al., 2012) and antitumor (Du et al., 2010) activities.

Some heavy metals at high concentration affect the growth of fungi and their metabolic pathway (Yasmin $\boldsymbol{e t}$ al., 2009). But, only relatively few studies have been carried out with heavy metal-metabolites relation including secondary metabolites. Thus, the current study aims to study the effect of Zinc at high concentrations on the pathways of natural secondary metabolites in tolerant Penicillium chrysogenum strain.

\section{MATERIALS AND METHODS}

\section{Isolation and purification of fungal strain}

Isolation and purification of fungal strain from sand at East Algerian polluted beaches (with $7.8 \mathrm{mg} . \mathrm{Kg}^{-1}$ of Zinc) were performed on Potatoes Dextrose Agar medium (PDA) at $25^{\circ} \mathrm{C}$ for 7 days (Ezzouhri et al., 2009). This strain was screened on $1000 \mathrm{mg} . \mathrm{l}^{-1}$ of Zinc for its ability to produce secondary metabolites.

\section{Optimization of fungal strain's growth}

The growth of Penicillium chrysogenum was studied at different temperature and $\mathrm{pH}$ values on CYA (Iram et al., 2013); $\mathrm{pH}$ values were 1, 6 and 12 . While temperature was ranging from 5 to $45^{\circ} \mathrm{C}$.

\section{Tolerance Index}

The tolerance index (TI) is an indication of the organism response to metal stress (Le et al., 2006). It was calculated as the ratio of the extended radius of the 
treated colony to that of the untreated colony strain on CYA at $25 \pm 2{ }^{\circ} \mathrm{C}$ after 7 days.

$\mathbf{T I}=\frac{\mathbf{D t}}{\mathbf{D u}}$, Where $D t$ : is the diameter of radial extension $(\mathrm{cm})$ of treated colony and $D u$ : is the radial extension (cm) of untreated colony (control) (Iram et al., 2013)

\section{Bioaccumulation of Zinc}

The amount of Zinc absorbed by fungal strain was evaluated in CYA broth medium containing concentration from $200 \mathrm{mg} \cdot \mathrm{l}^{-1}$ to $1400 \mathrm{mg} . \mathrm{l}^{-1}$ of Zinc with interval of $200 \mathrm{mg} \cdot \mathrm{l}^{-1}$. Five millimeters of agar plugs were inoculated in these flasks $(200 \mathrm{ml})$ from young fungal culture (7 days) and incubated on shaker at $150 \mathrm{rpm}, 25 \pm 2^{\circ} \mathrm{C}$ for 7 days with the control. Fungal biomass was harvested after 7 days through centrifugation at $9000 \times \mathrm{g}$ then was washed and dried $70^{\circ} \mathrm{C}$ for 3 $\mathrm{h}$, then was digested with nitric and perchloric acid (3:1 ratio). The digested fungal biomass was filtered using Whatman filter paper $\left(\mathrm{N}^{\circ} 1\right)$, then the volume was completed to $50 \mathrm{ml}$. Heavy metal uptake was estimated using Atomic Absorption Spectrophotometer (Deepa et al., 2006; Ezeonuegbu et al., 2015).

\section{Microscopic observation of fungal mycelium at high concentration of Zinc}

The samples were mounted on a glass slide with sterilized drops of distilled water, and observed under light microscope. Microscopic observation was performed in order to distinguish any form of Zinc storage and demonstrate the modifications shown of hyphal tips (Lanfranco et al., 2002).

\section{Effect of Zinc on antibiotic production}

The identification of the secondary metabolites mainly antibiotics on a solid medium was achieved by the direct observation of the medium pigmentation and the outline of the fungal colonies (Sajjad $\boldsymbol{e t}$ al., 2012). The presence of $\beta$-lactam antibiotics at high concentrations of Zinc was assessed using qualitative disc test assay of the extract of $P$. chrysogenum grown in the presence of Zinc at high concentrations (1200 and $1400 \mathrm{mg} . \mathrm{l}^{-1}$ ) against Escherichia coli strain (ATCC 25312) (Ali et al., 2011).

Effect of Zinc on mycotoxin production

\section{On Thin Layer Chromatography (TLC)}

The basal aqueous CYA medium of the Penicillium chrysogenum culture was subjected to a liquid-liquid extraction with ethyl-acetate thrice ( $99.5 \%$ purity) after 14 days old culture. The whole $P$. chrysogenum biomass was removed through centrifugation $(9000 \times \mathrm{g})$ followed by filtration of liquid medium through filter paper Whatman $\left(\mathrm{N}^{\circ} 1\right) .10 \mu 1$ of obtained extracts were applied on sheet of silica gel layer as stationary phase. The compounds were separated for the mycotoxin detection on TLC plates using a mixture of solvent systems: Butanol, acetic acid, water (1/ 1/ 1) and chloroform, methanol $(90 / 10)$. The plates were dried using hair-dryer then were examined under long UV light $(365 \mathrm{~nm})$. The characteristics of all spots, that is, colour and retention factor $\left(R_{f}\right)$ value were recorded (Paterson et al., 1994; Vinokurova et al., 2001; Zain et al., 2011).

\section{On High Performance Liquid Chromatography (HPLC)}

The TLC's positive samples were analyzed by HPLC system. The HPLC system "JASCO" have reversed phase is equipped with C18 column (ODS $5 \mu \mathrm{m}$. $25 \times$ $0.46 \mathrm{~cm}$ ) and mass spectrometry (MS) fragmentation spectra; the mobile phase was methanol. Analysis of mycotoxin from 14 days old culture of $P$. chrysogenum was carried in CYA medium using Zinc concentrations of the TLC's positive. The extract was filtered through filter paper and left at $4{ }^{\circ} \mathrm{C}$ for 1 hour, Then was further filtered through a Whatman $\left(\mathrm{N}^{\circ} 1\right), 0.45$ micron and 0.22 micron filters. This filtrate was divided into $50 \mathrm{ml}$ aliquots and stored in the dark at $4{ }^{\circ} \mathrm{C}$ until use with the control sample. A C18 gravity column was wetted with $100 \mathrm{ml}$ of methanol and then washed with $50 \mathrm{ml}$ of distilled water. A $50 \mathrm{ml}$ aliquot of extract was added to the column and allowed to adsorb. The flow rate was $1.0 \mathrm{ml} . \mathrm{min}^{-1}$, and the running conditions were as follows: 1-3 min, buffer A (50 $\mathrm{mM}$ sodium acetate); $3-15 \mathrm{~min}$, gradient buffer B ( 0 to $60 \%$ acetonitrile); 15 $18 \mathrm{~min}$, gradient buffer B (60 to $80 \%$ acetonitrile); $18-20 \mathrm{~min}$, buffer B (80\% acetonitrile); 20-22 min, gradient buffer B (80\%to $0 \%$ acetonitrile); and 22- 25 min, buffer A (50 mM sodium acetate) 18, 19, 20 (Onyegeme-Okerenta et al., 2013).

\section{Statistical Analysis}

Each treatment of all above experiments was conducted in triplicate and the average values were used in the data analysis. The optimization of fungal growth and the TI results of Zinc were expressed as mean \pm standard deviation (SD) using SPSS20.

\section{RESULTS AND DISCUSSION}

\section{Optimization of fungal strain's growth}

Penicillium chrysogenum strain showed rapid growth at $\mathrm{pH}=6$ rate with $90 \%$. At $\mathrm{pH}=12$, the growth rate was estimated about $66 \%$. Under the same conditions there is a slow growth $(24 \%)$ at $\mathrm{pH}=1$ (Figure 1$)$. The optimum $\mathrm{pH}$ value of growth was 5.5-6. Therefore, this $\mathrm{pH}$ may be used for further study. Similar observations were made by Abdul Rasol et al. (2009). The ability of $P$ chrysogenum to grow on extreme $\mathrm{pH}$ can be explained effectively by the intracellular changes to maintain the membrane potential in relation to the external environment, these changes involve control of proton movement intra and extracellular. It is also linked to control of osmotic pressure due to the involvement of cations and anions (Magan, 2007). Penicillium chrysogenum showed a slow growth at $5{ }^{\circ} \mathrm{C}(45 \%)$. Good growth with rate $150 \%$ was observed at $37{ }^{\circ} \mathrm{C}$, when at $45{ }^{\circ} \mathrm{C}$ and $5{ }^{\circ} \mathrm{C}$ temperature, growth rates were $90 \%$ and $42 \%$ respectively (Figure 2).

The optimal temperature was found $27-30^{\circ} \mathrm{C}$, but it was a thermotolerant strain (at $45^{\circ} \mathrm{C}$ ). Similar results were reported by Kubicek and Druzhinina (2007) who recorded that $P$. chrysogenum is a thermotolerant strain up at $45^{\circ} \mathrm{C}$, at the same time it is psychrotolerant. Several hypotheses have been proposed to explain the resistance to high temperature: 1) solubilization of lipids; 2) rapid resynthesis of essential metabolites; 3 ) molecular thermo-stability.

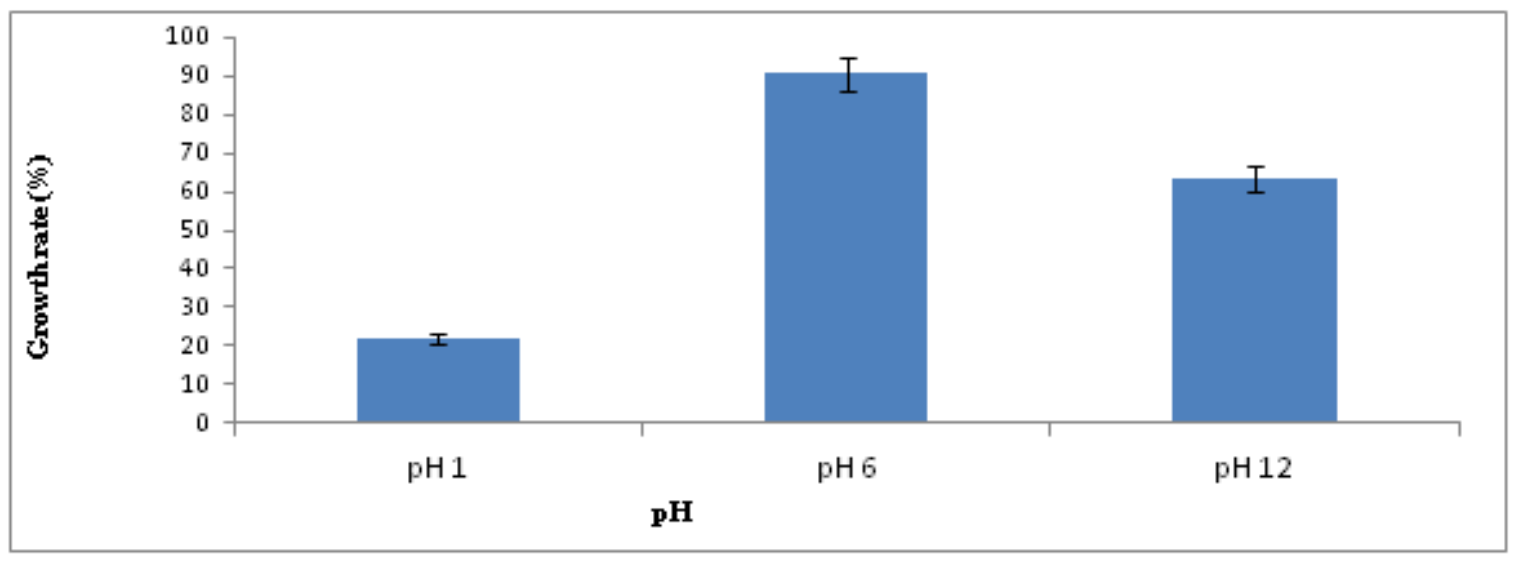

Figure 1 Effect of $\mathrm{pH}$ on growth of Penicillium chrysogenum at $5 \pm 2{ }^{\circ} \mathrm{C}$ after 7 days on $\mathrm{CYA}$ 


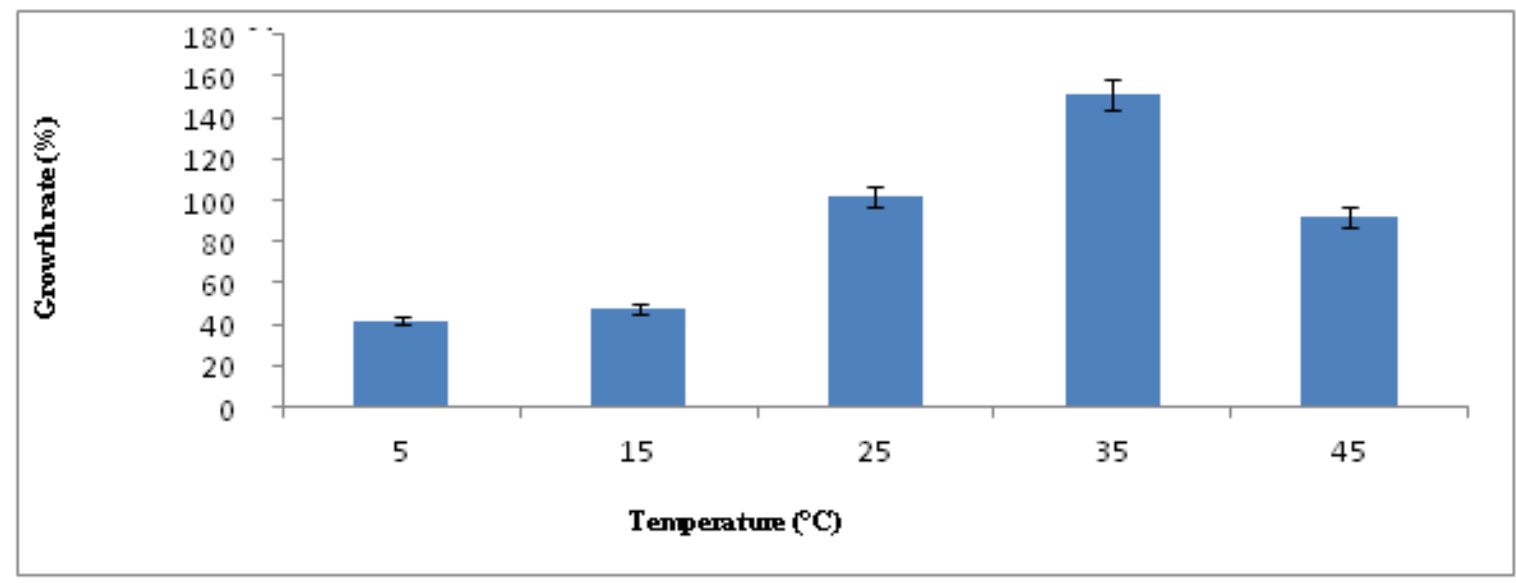

Figure 2 Effect of temperature on growth of Penicillium chrysogenum after 7 days on CYA

\section{Tolerance index}

The tolerance index (TI) is an indication of the Penicillium chrysogenum response to metal stress (Le et al., 2006). It was observed that Penicillium chrysogenum used more adaptive mechanisms of resistance at the higher concentration (1200 mg..$^{-1}$ ) with rates of TI; 35\% (Figure 3). It is able to develop and continue its growth in presence of Zinc in the medium at high concentration $\left(1400 \mathrm{mg} . \mathrm{l}^{-1}\right)$ with rates of TI; $18 \%$. This is in agreement with results reported by
Ezzouhri et al. (2009) who founded that this subgenus was able to tolerate up to $1000 \mathrm{mg} . \mathrm{l}^{-1}$ Zinc, and Sharma et al. (2014) who demonstrated that $P$. chrysogenum can tolerate Zinc up to $1200 \mathrm{mg}^{-1} \mathrm{l}^{-1}$. Different types of tolerance processes or resistance mechanisms were exposed by different fungal species, the used of culture medium can have a great influence on the maximum tolerated values by this fungal strain (Shivakumar et al., 2014).

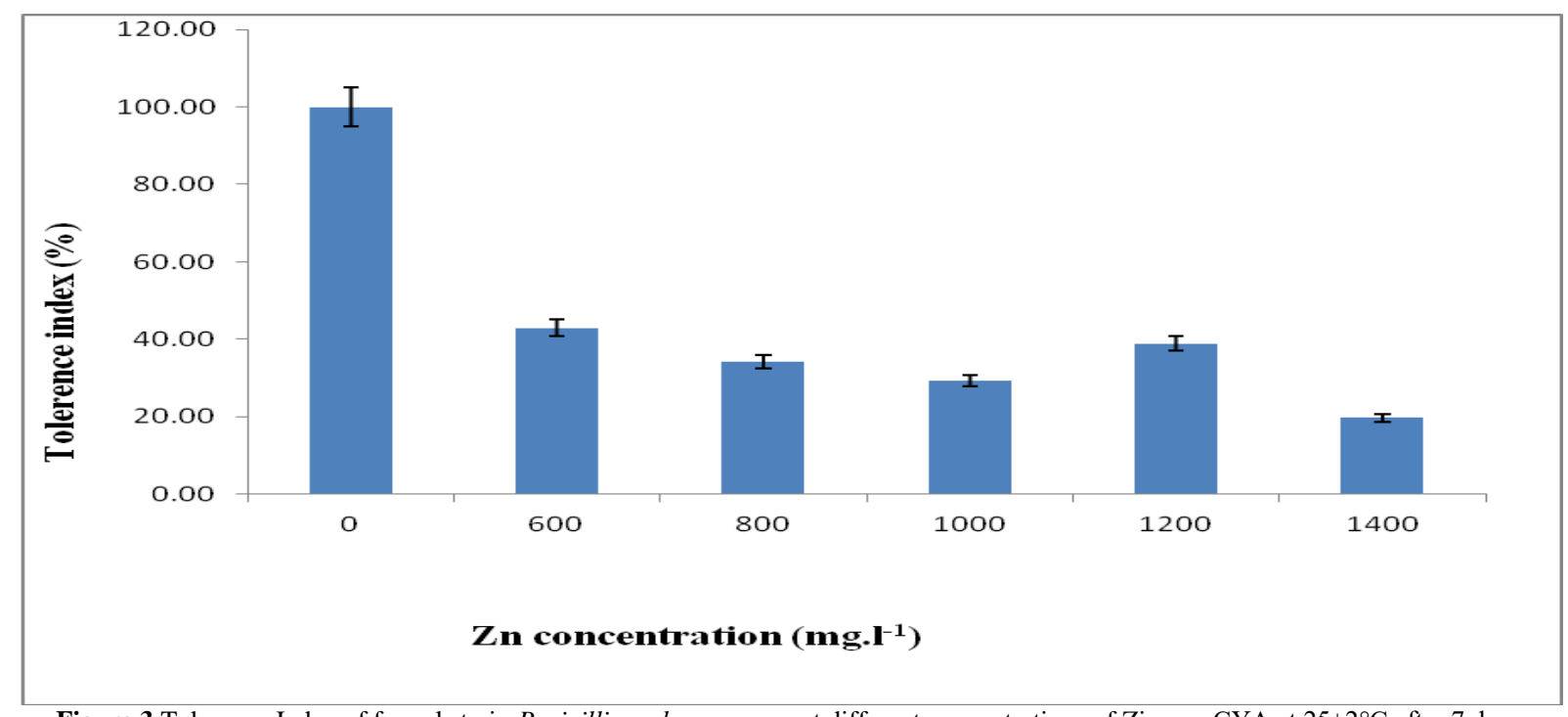

Figure 3 Tolerance Index of fungal strain Penicillium chrysogenum at different concentrations of Zinc on CYA at $25 \pm 2^{\circ} \mathrm{C}$ after 7 days

\section{Zinc bioaccumulation}

This test only allows us to estimate the amount of the metal uptaken using the screened fungal strain at different concentrations against the control without addition of Zinc (Figure 4). The ability of the strain to accumulate this metal increased rapidly with increasing the initial concentrations of Zinc to a maximum value $\left(248 \mathrm{mg} \cdot \mathrm{g}^{-1}\right)$ at $1200 \mathrm{mg} \cdot \mathrm{l}^{-1}$. This accumulation capacity decreased until reaching a value of $155 \mathrm{mg} \cdot \mathrm{g}^{-1}$ at $1400 \mathrm{mg} \cdot \mathrm{l}^{-1}$. These results are correlated with the observations obtained from the tolerance index (Figure 3). In the same context, the capacity of Penicillium chrysogenum on Zinc uptake is explained by the biosorption of extra-cellular mechanisms through cell wall which exhibits excellent metal binding properties as it is negatively charged due to the presence of various anionic structures, such as glucan and chitin, this gives fungus the ability to bind metal cations (Anahid et al., 2011), or by the intra-cellularly accumulation with transport proteins of metal compounds that may be involved in metal tolerance: efflux out of the metal ion cell or by compartmentalization in vacuoles or additionally, by complication with cytoplasmic proteins called metallothioneins (Siddiquee et al., 2015).

As above-mentioned, chemical changes methods could increase/activate the binding sites on the biomass surface, they include pretreatment, binding site enhancement, binding site change and polymerization, e.g the grafting of long polymer chains onto the biomass surface through direct grafting or polymerization of a monomer could introduce functional groups onto the surface of biomass ( Vijayaraghavan et al., 2008). 


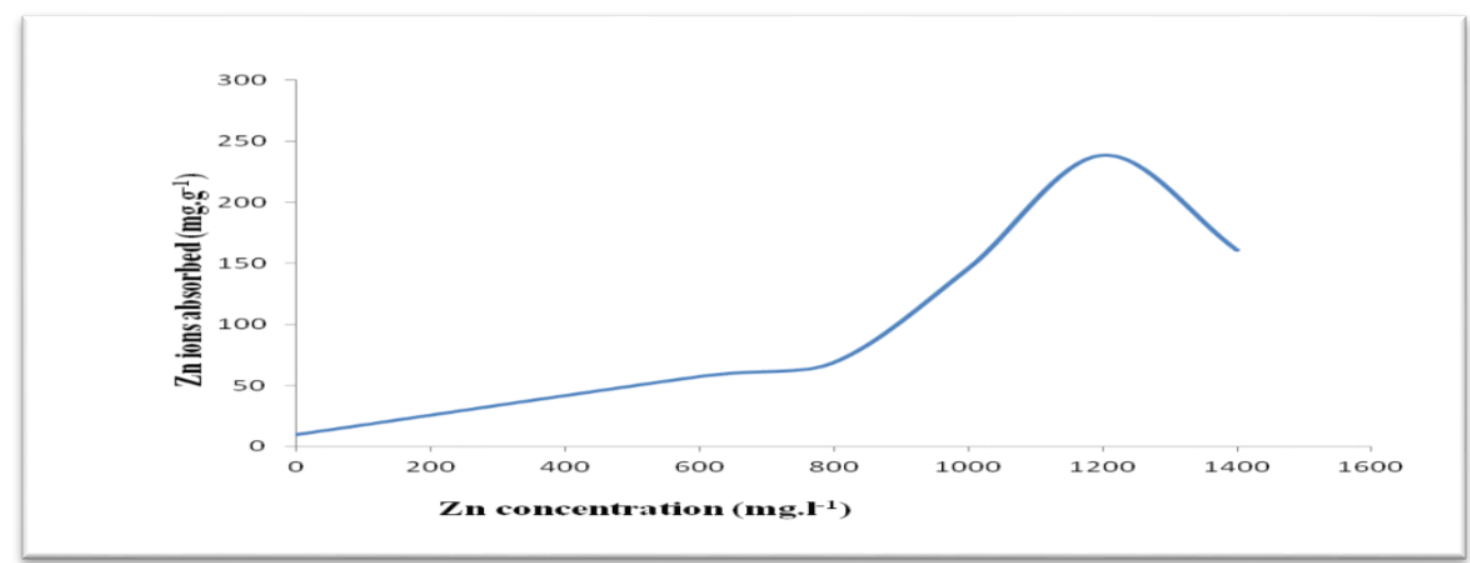

Figure 4 Bioaccumulation of Zinc by Penicillium chrysogenum in CYA broth at $25 \pm 2{ }^{\circ} \mathrm{C}$ after 7 days

\section{Microscopic observation of fungal cell}

Here, investigated microscopic observation was unexpected (Figure 5). The microscopic observation contradicts all the theories mentioned before (Avery $\boldsymbol{e t}$ al., 2007), excepting those that were previously proposed which said that efflux of Zinc back into compartmentalization in the organelles or in vacuoles (Blaudez et al., 2000; Eide et al., 2003).

In the absence of Zinc in the medium, fungal hyphae grew using apical growth with a typical tapered apex and absence of branching from the tip. The presence of high concentrations of Zinc did modify the hyphal morphology, and the mos characteristic features of Zinc-treated hyphae, when compared to control samples, were the overall increase in hyphal branching, swelling and septation. At high concentration of Zinc in the medium, fungal hyphae grew with pattern resulted in parallel-oriented hyphae that were loose at the edge of the colony and organized in bundles that sometimes coiled in the inner part. Therefore, hyphae became increasingly vacuolated with rounded refractive vacuoles (Lanfranco $\boldsymbol{e t}$ al., 2002) as indicated in Figure 5.

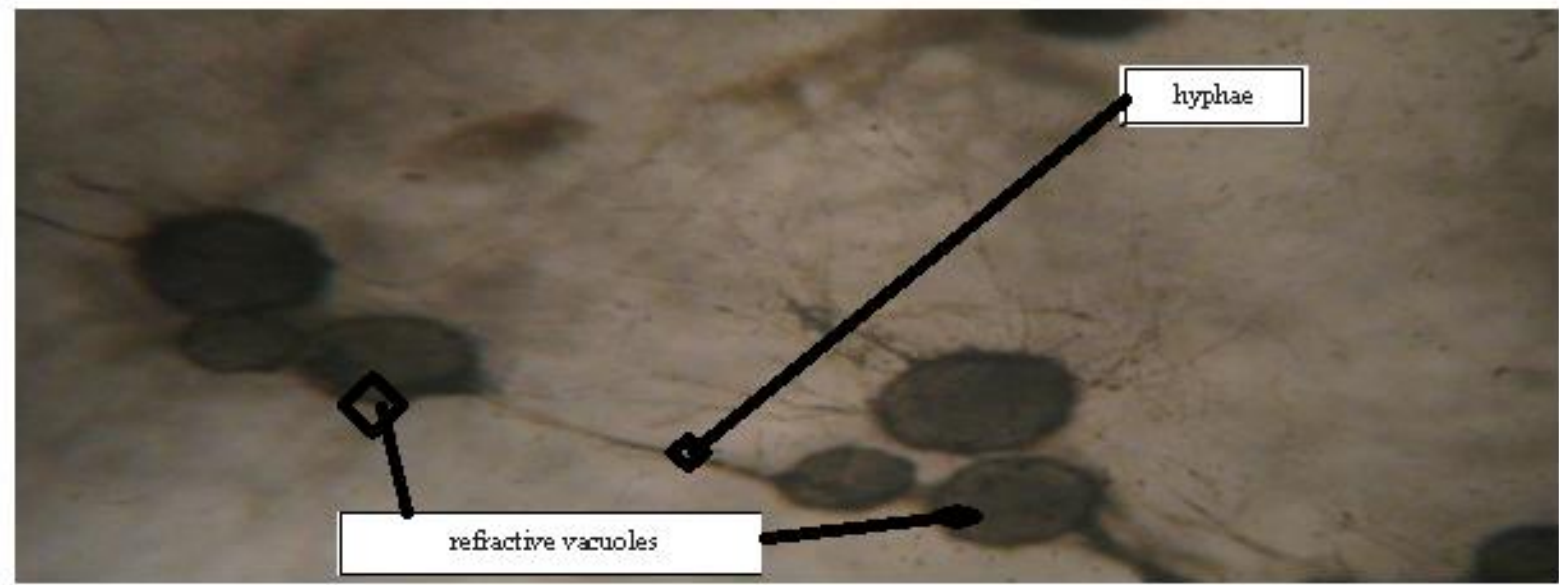

Figure 5 Microscopic observation of Penicillium chrysogenum mycelium at $1200 \mathrm{mg} . \mathrm{l}^{-1}$ of Zinc $(60 \times)$

\section{Effect of Zinc on antibiotic production}

The growth of Penicillium chrysogenum on CYA medium appeared in yellowish brown and bluish-colored, powdery and velvety-textured colonies with a white outline (Figure $6 \mathrm{a}, \mathrm{b}, \mathrm{c}$ ). Highlighted of secondary metabolite production by $P$. chrysogenum on CYA revealed that there is antibiotic production at the highest concentration of Zinc (1400 mg. $\left.\mathrm{l}^{-1}\right)$. On the same medium, bluish-colored with a white outline colour indicated that observed colonies represent $P$. chrysogenum species. Their mycelium becomes thick in comparison to the control Additionally, growth of the Penicillium chrysogenum on CYA medium at high concentrations of Zinc ions was accompanied by a yellow substance production which is a response to the stress induced in the presence of Zinc in the medium.
The efforts of researchers are still focused on Penicillium species as a continuous source of antibiotic production. The routine disc assay of the antibiotic production showed production of $\beta$-lactam antibiotics, at least the penicillin in the medium. Sajjad et al. (2012) isolated penicillin from a pure culture of the $P$. chrysogenum strain on CYA medium. Thus, the colored substance indicates the production of secondary metabolites by $P$. chrysogenum strain which may be an antibiotic such as $\beta$-lactam (penicillin ... Etc.). As shown in Table 1, it is interesting to note that there is a remarkable inhibition of extracts of $P$. chrysogenum against $E$. coli strain. Optimum production of antibiotic was obtained at Zinc concentration of $1400 \mathrm{mg} \cdot \mathrm{l}^{-1}$ which gave the maximum zone of inhibition during disc test with diameter $3.8 \pm 0.7 \mathrm{~cm}$.
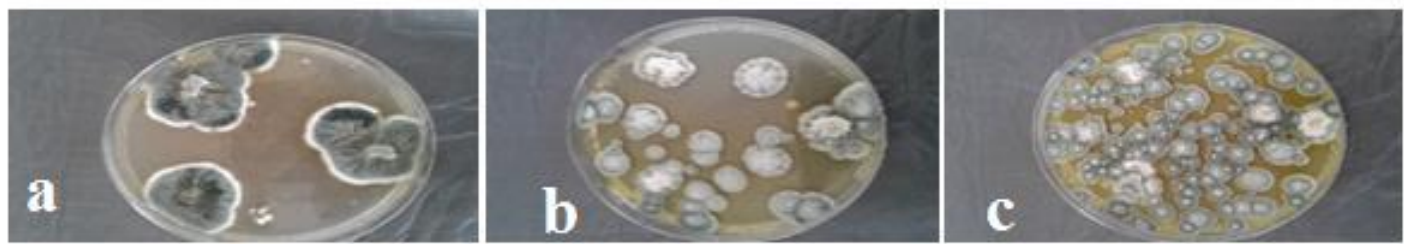

Figure 6 Colony aspect of Penicillium chrysogenum after 7 days on CYA at $25^{\circ} \mathrm{C}$ at different concentrations of Zinc (a: control, b: $1200 \mathrm{mg} .1^{-1}, \mathrm{c}: 1400 \mathrm{mg} .1^{-1}$ ) 
Table 1 Diameter of zone inhibition of extracts of $P$. chrysogenum against E.coli strain ATCC 25312 (mean \pm SD)

\begin{tabular}{|c|c|c|c|}
\hline Diameter & control & $1200 \mathrm{mg.l}^{-1}$ & $1400 \mathrm{mg.l}^{-1}$ \\
\hline Extracts of $P$. chrysogenum & $2.4 \pm 0.06$ & $2.9 \pm 0.6$ & $3.8 \pm 0.2$ \\
\hline
\end{tabular}

\section{Effect of Zinc on mycotoxin production}

\section{On TLC}

The mycotoxin were detected as fluorescent spots in UV-chamber at $365 \mathrm{~nm}$. The revelation of the plate (TLC) allowed us to separate two spots corresponding to the mycotoxins produced by the Penicillium chrysogenum strain. The two spots 1,2 have a retention factor $R_{f}=0.65, R_{f}=0.64$, respectively. Figure 7 demonstrated that there is a spot 1 corresponding to the production of a metabolite in the control and a spot 2 corresponding also to the production this metabolite at $800 \mathrm{mg} . \mathrm{l}^{-1}$ of Zinc. The retention factor of the control $(0.65)$ is almost the same at concentration of $800 \mathrm{mg} . \mathrm{l}^{-1}$, indicating that both spots correspond to the same mycotoxin. At the higher concentrations (1200 and 1400 $\mathrm{mg} . \mathrm{l}^{-1}$ ), there is no migration of the molecules (spots 3 and 4). Thus, there is no production of these mycotoxins at the high concentrations. Compared to the results obtained in Figure 39b and 40c, the growth of Penicillium chrysogenum at the highest concentration of Zinc ion (1400 mg. $\left.\mathrm{l}^{-1}\right)$ showed production of yellow substance that is strongly an antibiotic. Thus, the present investigation indicates that the highest concentration of Zinc (1400 mg. $\left.{ }^{-1}\right)$ has a positive effect on antibiotic production, but there is a negative effect on the production of mycotoxin (TLC). Penicillium chrysogenum synthesizes mycotoxins from the alkaloid family and certain mycotoxins from the sterol (Sunesson et al., 1996; Lugauskas et al., 2005). From TLC plate result, it is evident that the mycotoxin production was inhibited at the highest concentration of Zinc (1400 mg. $\left.1^{-1}\right)$.

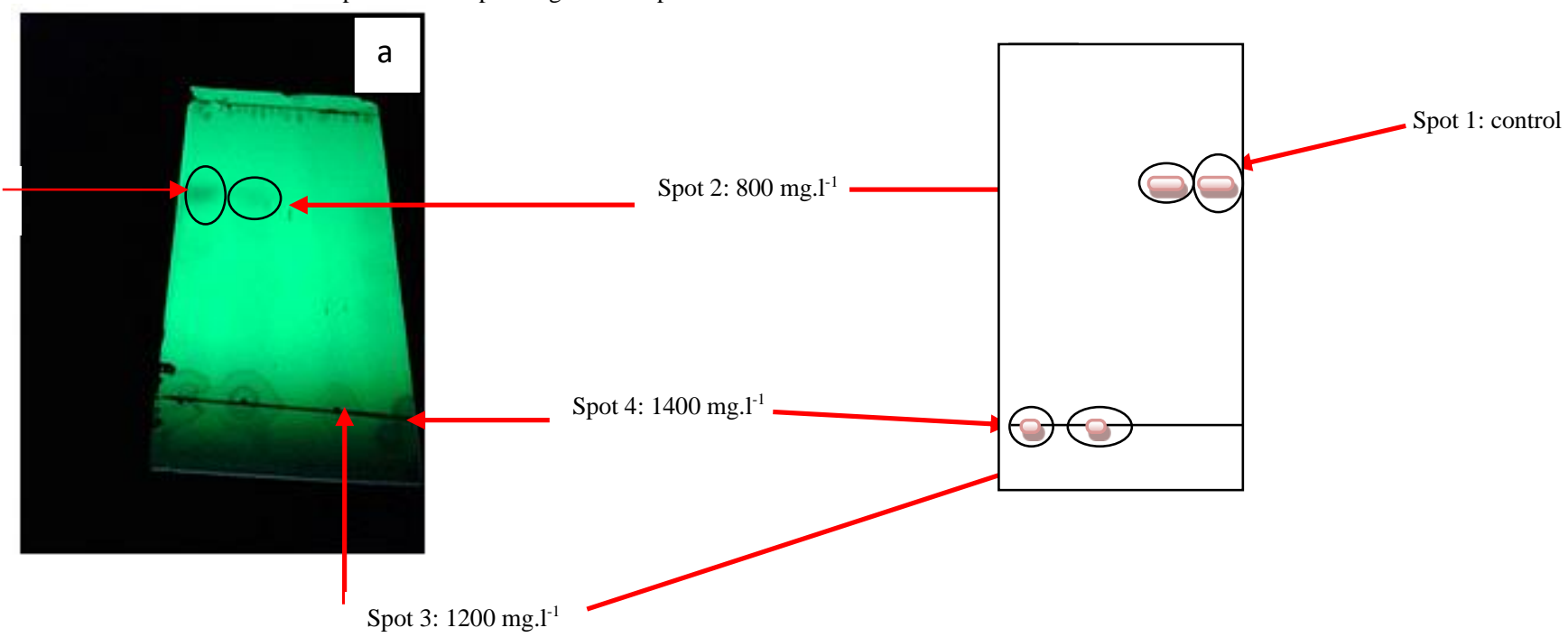

Figure 7 Separation of mycotoxin from Penicillium chrysogenum grown in the presence of Zinc with the high concentrations on TLC sheet under long UV light with $365 \mathrm{~nm}$ (a: real photo, b: schematic illustration)

\section{On HPLC}

In present study, we described the identification of various abundant metabolites. As illustrated in Table 2, the identification of four compounds was confirmed by comparing retention time as was described by Ries et al. (2013). HPLC elution profiles of the control indicated the presence of several clearly peaks (around 7). Comparing retention time and MS fragmentation spectra allowed us to identify four compounds: Peak (12), at $15.1 \mathrm{~min}$ as roquefortine N. Peak (11) at $16.5 \mathrm{~min}$ as roquefortine C. Peak (10) at $17.8 \mathrm{~min}$ such as neoxaline, peak (9) at $22.2 \mathrm{~min}$ as roquefortine F. The others were not identified: peak (13) at 13.5 min, peak (8) at $25.7 \mathrm{~min}$ and peak (7) at $28.5 \mathrm{~min}$ (Figure $8 \mathrm{~A}$ )
HPLC elution profiles of P.chrysogenum extract at $1200 \mathrm{mg} . \mathrm{l}^{-1}$ of Zinc suggested the production of three mycotoxins: non-identified peak at $13.5 \mathrm{~min}$. neoxaline as peak (10) at $17.8 \mathrm{~min}$. roquefortine $\mathrm{F}$ as peak (9) at $22.8 \mathrm{~min}$ (Figure $8 \mathrm{~B}$ ). The extract of P.chrysogenum at $1400 \mathrm{mg} . \mathrm{l}^{-1}$ of Zinc indicated that a single mycotoxin was produced which is neoxaline showed in peak (10) at 17.8 min (Figure 8C) The reported results demonstrated that the high concentrations of Zinc (1200 and $1400 \mathrm{mg} \cdot \mathrm{l}^{-1}$ ) inhibit some branches of the secondary metabolite pathway yielding variety of intermediates as explained by Ries et al. (2013) in roquefortine / Meleagrin pathway via inhibition of enzyme activity. The concentration of 1200 $\mathrm{mg} . \mathrm{l}^{-1}$ has an influence on yielding of variety intermediates between the precursor and roquefortine F. While, $1400 \mathrm{mg} \cdot \mathrm{l}^{-1}$ of Zinc affects the metabolic pathway between the precursor and the final product which was identified as neoxaline.

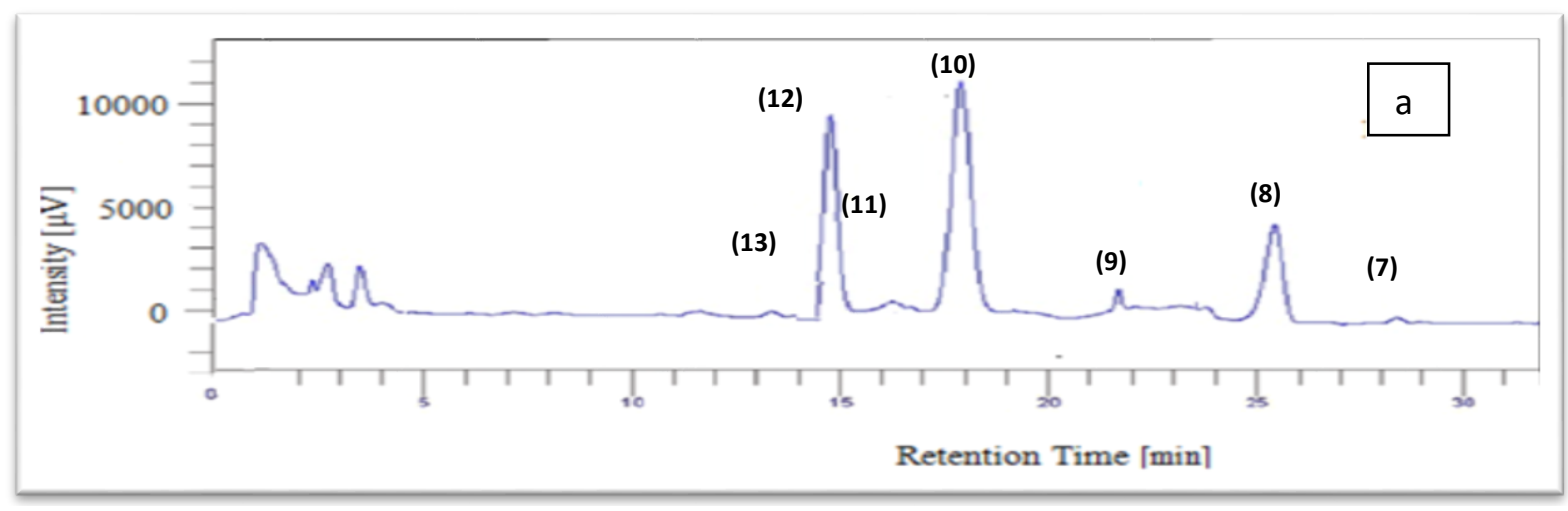



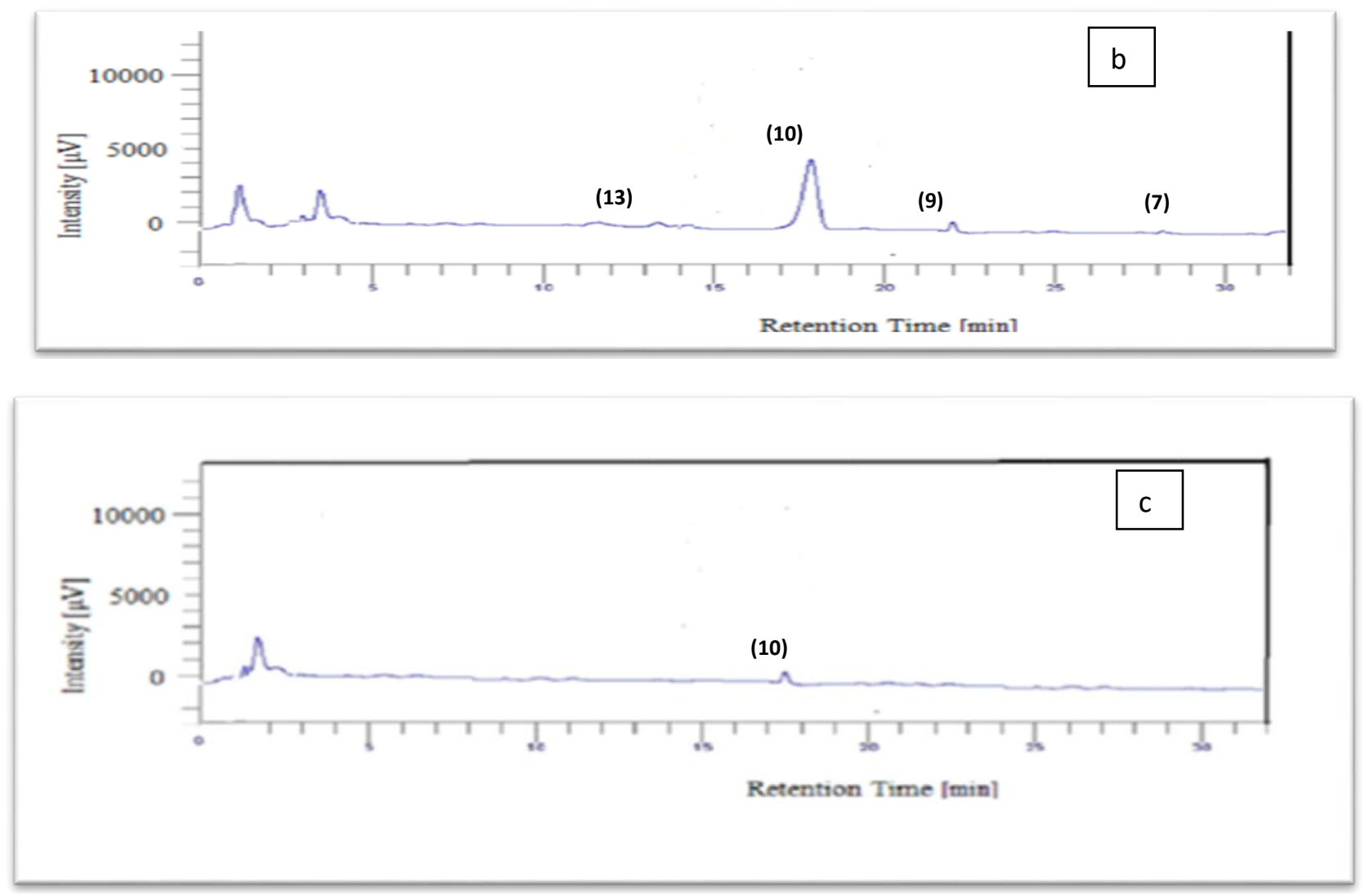

Figure 8 HPLC elution profiles of $P$. chrysogenum mycotoxins (a: control, b: at $1200 \mathrm{mg} \cdot \mathrm{l}^{-1}$ and c: at $1400 \mathrm{mg} \cdot \mathrm{l}^{-1}$ of Zinc)

Table 2 Description of the molecules and the Rt of HPLC peaks

\begin{tabular}{lll}
\hline Molecule & Peak & Retention time (Rt) / min \\
\hline non identified & 7 & 28.5 \\
non identified & 8 & 25.7 \\
roquefortine F & 9 & 22.8 \\
neoxaline & 10 & 17.8 \\
roquefortine C & 11 & 16.5 \\
roquefortine N & 12 & 15.1 \\
non identified & 13 & 13.5 \\
\hline
\end{tabular}

\section{CONCLUSION}

In conclusion, the addition of Zinc with the highest concentration (1400 mg. $\mathrm{l}^{-1}$ ) into the incubation medium Penicillium chrysogenum affects positively antibiotics production and negatively mycotoxin production except to neoxaline. Finally, much remains to be understood about the influence of high concentration of heavy metals (as Zinc) on metabolic pathways of tolerant fungal strains.

\section{REFERENCES}

ABDUL RASOL, K.H.A., Ali, E. A., Khalil, I.B. 2009. Isolation and identification of antibiotics produced by Penicillium brasilianum batista isolated from salahaddin province soils. Thi-Qar Medical Journal, 1, 71-87.

ALI, A., HAIDER, M.S., KHOKHAR, I., BASHIR, U., MUSHTAQ, S. MUKHTAR, I. 2011. Antibacterial activity of culture extracts of Penicillium species against soil-borne bacteria. Mycopathologia, 9(1), 17-20.

ANAHID, S., YAGHMAEI, S., GHOBADINEJAD, Z. 2011. Heavy metal tolerance of fungi. Scientia Iranica, 18, 502-508. https://doi.org/10.1016/j.scient.2011.05.015

AVERY, S., STRATFORD, M., VAN WEST, P. 2007. Stress in Yeasts and Filamentous Fungi (1 $1^{\text {st }}$ Ed). Academic Press, British.

BLAUDEZ, D., BOTTON, B., CHALOT, M. 2000. Cadmium uptake and subcellular compartmentation in the ectomycorrhizal fungus Paxillu involutus. Microbiology, 146, 1109-1117. http://dx.doi.org/10.1099/00221287146-5-1109

CLARK, B., CAPON, R. J., LACEY, E., TENNANT, S., GILL, J.H. 2005. Roquefortine E, a diketopiperazine from an Australian isolate of Gymnoascus reessii. Journal of Natural Products, 68, 1661-1664. http://dx.doi.org/10.1021/np0503101

DEEPA, R., SENTHILKUMAR, P., SIVAKUMAR, S., DURAISAMY, P., SUBBHURAAM, C.V. 2006. Copper Availability and Accumulation by Portulaca oleracea Linn. Environmental Monitoring and Assessment, 116, 185 195. http://dx.doi.org/10.1007/s10661-006-7235-z
DU, L., FENG, T., ZHAO, B., LI, D., CAI, S., ZHU, T., WANG, F., XIAO, X., GU, Q. 2010. Alkaloids from a deep ocean sediment-derived fungus Penicillium sp., and their antitumor activities. Journal of Antibiotics, 63, 165-170. http://dx.doi.org/10.1038/ja.2010.11

EIDE, D.J. 2003. Multiple regulatory mechanisms maintain Zinc homeostasis in Saccharomyces cerevisiae. Journal of Nutrition, 133(5), 1532S-5S https://doi.org/10.1093/jn/133.5.1532S

EZEONUEGBU, B.A., MACHIDO, D.A., YAKUBU, S.E. 2015. Capacity of fungal genera isolated from refinery effluents to remove and bioaccumulate Lead, Nickel and Cadmium from refinery waste. The International Journal of Science and Technoledge, 3 (6), 47-52.

EZZOUHRI, L., CASTRO, E., MOYA, M., ESPINOLA, F., LAIRINI, K. 2009. Heavy metal tolerance of filamentous fungi isolated from polluted sites in Tangier, Morocco. African Journal of Microbiology Research, 3 (2), 035-048. http://dx.doi.org/10.7745/KJSSF.2012.45.4.565

FOX, E.M., HOWLETT, B.J. 2008. Secondary metabolism: regulation and role in fungal biology. Current Opinion in Microbiology, 11, 481-487. http://dx.doi.org/10.1016/j.mib.2008.10.007

GLOER, J.B. 2007. Applications of fungal ecology in the search for new bioactive natural products. In: Wicklow DT, Soderstrom BE (eds) The Mycota. Springer-Verlag, New York IV. p 257-283.

IRAM, S., ZAMAN, A., IQBAL, Z., SHABBIR, R. 2013. Heavy metal tolerance of fungus isolated from soil contaminated with sewage and industrial wastewater. Polish Journal of Environmental Studies, 22, 691-697.

KEATING, G., FIGGITT, D. 2003. Caspofungin: A review of its use in oesophageal candidiasis, invasive candidiasis and invasive aspergillosis. Drugs, 63, 2235-2263. http://dx.doi.org/10.2165/00003495-200363200-00008

KOOLEN, H.H., SOARES, E.R., SILVA, F.M., SOUZA, A.Q.,MEDEIROS, L.S., FILHO, E. R., ALMEIDA, R. A., RIBEIRO, I. A., PESSOA CDO, O'., MORAIS, M. O. et al. 2012. An antimicrobial diketo piperazine alkaloid and cometabolites from an endophytic strain of Gliocladium isolated from Strychnos cf.toxifera. $\quad$ Natural Product Research, 20, 2013-2019 http://dx.doi.org/10.1080/14786419.2011.639070

KRÄMER, U., CHARDONNENS, A.N. 2001. The use of transgenic plants in the bioremediation of soils contaminated with trace elements. Applied Microbiology and Biotechnology, 55 http://dx.doi.org/10.1007/s002530100631

KUBICEK, P., DRUZHININA, I.S. 2007. Environmental and Microbia Relationships ( $2^{\text {nd }}$ ed). Springer, Bochum, Germany. p 279-291.

MAGAN, N. 2007. Fungi in extreme environments. The Mycota IV, Environmental and Microbial Relationships (Kubicek CP \& Druzhinina IS, eds). Springer Verlag, Berlin. p 85-103. 
LANFRANCO, L., BALSAMO, R., MARTINO, E., PEROTTO, S., BONFANTE, P. 2002. Zinc ions alter morphology and chitin deposition in an ericoid fungus. European Journal Of Histochemistry, 46, 341-350.

LE, L., TANG, J.. RYAN, D., VALIX, M. 2006. Bioleaching nickel laterite ores using multi-metal tolerant Aspergillus foetidus organism. Minerals Engineering, 19, 1259-65. https://doi.org/10.1016/j.mineng.2006.02.006

LOPEZERRASQUÍN, E., VÁZQUEZ, C. 2003.Tolerance and uptake of heavy metals by Trichoderma atroviride isolated from sludge. Chemosphere, 50, 137143. https://doi.org/10.1016/S0045-6535(02)00485-X

LUGAUSKAS, A., RAUDONIENE, V., SVEISTYTE, L. 2005. Toxin producing micromycetes on imported products of plant origin. Annals of Agricultural and Environmental Medicine, 12(1), 109-118. https://doi.org/10.26444/aaem/92252

ONYEGEME-OKERENTA, B.M., OKOCHI, V.I., CHINEDU, S.N. 2013. Penicillin Production by Penicillium Chrysogenum PCL 501: effect of UV induced mutation. Internet Journal of Microbiology, 12 (1).

PARAMESWARI, E., LAKSHMANAN, A., THILAGAVATHI, T. 2010 Biosorption and metal tolerance potential of filamentous fungi isolated from metal polluted ecosystem. The Electronic Journal of Environmental, Agricultural and Food Chemistry, 9(4), 664-671.

PATERSON, R.R.M., BRIDGE, P.D. 1994. Biochemical Techniques for Filamentous Fungi. IMI Techniques Series no. 1. Wallingford, UK: CABI. RIES, M.I, ALI, H., LANKHORST, P.P., HANKEMEIER, T., BOVENBERG, R.A., DRIESSEN, A.J., VREEKEN, R.J. 2013. Novel key metabolites reveal further branching of the roquefortine/meleagrin biosynthetic pathway. Journal of $\begin{array}{lllll}\text { Biological Chemistry, } & 288 & \text { (52), } & 37289 & -37295 .\end{array}$ https://doi.org/10.1074/jbc.M113.512665 SAJJAD, U., MUHAMMAD, H.R., MUHAMMAD, R. 2012. Penicillin production by wild isolates of Penicillium chrysogenum in pakista Brazilian Journal of Microbiology, 43(2), 476-481. https://dx.doi.org/10.1590\%2FS1517-83822012000200007

SAXENA, P., BHATTACHARYYA, A., MATHUR, N. 2006. Nickel tolerance and accumulation by filamentous fungi from sludge of metal finishing industry. Geomicrobiology Journal, 23 (8), 333-340. https://dx.doi.org/0.1038/ja.2010.11 SCOTT, P. M., MERRIEN, M. A., POLONSKY, J. 1976. Roquefortine and isofumigaclavine A, metabolites from Penicillium roqueforti. Experientia, 32,140-142.

SHARMA， N.K., BENIWAL， V., KUMAR， N., KUMAR， S., PATHERA, A.K., RAY, A. 2014. Production of tannase under solid-state fermentation and its application in detannification of guava juice. Preparative Biochemistry \& Biotechnology, $\quad$ 44(3), 281-290. http://dx.doi.org/ 10.1080/10826068.2013.812566

SHIVAKUMAR, C.K., THIPPESWAMY, B., KRISHNAPPA, M. 2014 Optimization of heavy metals bioaccumulation in Aspergillus niger and Aspergillus flavus. Journal of Environmental Biology, 4(2), 188-195.

SIDDIQUEE, S., ROVINA, K., AL AZAD, S., NAHER, L., SURYANI, S., CHAIKAEW, P. 2015. Heavy Metal Contaminants removal from wastewater using the potential filamentous Fungi biomass. Journal of Microbial and Biochemical Technology, 7(6), 384-393. http://dx.doi.org/10.4172/1948-5948.100024

SUNESSON, A.L., NILSSON, C.A. ANDERSSON, B., BLOMQUIST, G. 1996. Volatile metabolites produced by two fungal species cultivated on building materials. Annals of occupational hygiene, 40(4), 397-410 https://doi.org/10.1016/0003-4878(96)00002-6

VALEE, B.L., WACKER, W.E. 1970. Metalloprotein. In: Neuyath, H. (Ed.). The protein. Academic Press, New York. p 192.

VIJAYARAGHAVAN, K., YUN, Y-S. 2008. Bacterial biosorbents and biosorption. Biotechnology Advances, 26, 266-291 https://doi.org/10.1016/j.biotechadv.2008.02.002

VINOKUROVA, N.G., BOICHENKO, D.M., BASKUNOV, B.P., ZELENKOVA, N.F., VEPRITSKAYA, I.G., ARINBASAROV, M.U., RESHETILOVA, T.A. 2001. Minor alkaloids of the fungus Penicillium roquefortii Thom 1906. Applied Biochemistry and Microbiology, 37, 184-187. http://dx.doi.org/10.1023/A:1002836000147

WEBER, S.S., POLLI, F., BOER, R., BOVENBERG, R.A., DRIESSEN, A.J. 2012. Increased penicillin production in Penicillium chrysogenum production strains via balanced overexpression of isopenicillin $\mathrm{N}$ acyltransferase. Applied and Environmental Microbiology, 78, 7107-7113. https://dx.doi.org/10.1128\%2FAEM.01529-12

YASMIN, S., ABT, B., SCHRETTL, M., MOUSSA, T.A.A., WERNER, E. R., HAAS, H. 2009. The interplay between iron and Zinc metabolism in Aspergillus fumigatus. Fungal Genetics and Biology, 707-713. https://dx.doi.org/10.1016/j.fgb.2009.05.003

ZAIN, M.E., EL-SHEIKH, H.H., SOLIMAN, H.G., KHALIL, A.M. 2011. Effect of certain chemical compounds on secondary metabolites of Penicillium janthinellum and P. duclauxii. Journal of Saudi Chemical Society, 15, 239-246. https://doi.org/10.1016/j.jscs.2010.09.004 